Ambiente \& Água - An Interdisciplinary Journal of Applied Science
ISSN 1980-993X - doi:10.4136/1980-993X
www.ambi-agua.net
E-mail: ambi.agua@gmail.com

\title{
Retrieval and mapping of chlorophyll-a concentration from Sentinel-2 images in an urban river in the semiarid region of Brazil
}

\author{
ARTICLES doi:10.4136/ambi-agua.2488
}

Received: 25 Oct. 2019; Accepted: 26 Jan. 2020

\begin{abstract}
Alessandro Rhadamek Alves Pereira ${ }^{1 *(D)}$; João Batista Lopes $^{2}$ iD Giovana Mira de Espindola ${ }^{1}$; Carlos Ernando da Silva ${ }^{3}$
\end{abstract}

\begin{abstract}
${ }^{1}$ Departamento de Transportes. Programa de Pós-Graduação em Desenvolvimento e Meio Ambiente. Universidade Federal do Piauí (UFPI), Campus Universitário Ministro Petrônio Portella, S/N, CEP: 64049-550, Teresina, PI, Brazil. E-mail: giovanamira@ufpi.edu.br

${ }^{2}$ Departamento de Zootecnia. Programa de Pós-Graduação em Desenvolvimento e Meio Ambiente. Universidade Federal do Piauí (UFPI), Campus Universitário Ministro Petrônio Portella, S/N, CEP: 64049-550, Teresina, PI, Brazil. E-mail: lopesjb@uol.com.br

${ }^{3}$ Departamento de Recursos Hídricos, Geotecnia e Saneamento Ambiental. Programa de Pós-Graduação em Desenvolvimento e Meio Ambiente. Universidade Federal do Piauí (UFPI), Campus Universitário Ministro Petrônio Portella, S/N, CEP: 64049-550, Teresina, PI, Brazil. E-mail: carlosernando@ufpi.edu.br *Corresponding author. E-mail: alessandro.rhadamek@ufpi.edu.br
\end{abstract}

\begin{abstract}
Recently, the Poti river mouth region has experienced environmental impacts that resulted in a change of landscape in its dry season, highlighting the eutrophication and proliferation of phytoplankton, algae, cyanobacteria and aquatic plants. Considering the aspects related to water-quality monitoring in the semiarid region of Brazil from remote sensing, this study aimed to evaluate the performance of Sentinel-2A satellite data in the retrieval of chlorophyll-a concentration in Poti River in Teresina, Piaui, Brazil. The chlorophyll-a concentration retrieval and mapping methodology involved the study of the water surface reflectance in Sentinel-2A images and their correlation with the chlorophyll-a data collected in situ during the years 2016 and 2017. The results generated by the Chl-1, Ha et al. (2017), Chl-2, Page et al. (2018), and Chl-3, Kuhn et al. (2019) equations show the need for calibrating the algorithms used for the Poti River water components. However, the empirical algorithm Chl-2 shows a correlation has been established to identify the spatiotemporal variation of chlorophyll-a concentration along the Poti River broadly and not punctually. The spatial distribution of this pigment in maps derived from Sentinel-2A is consistent with the pattern of occurrence determined by the in situ data. Therefore, the MSI sensor proved to be a tool suitable for the retrieval and monitoring of chlorophyll-a concentration along the Poti River.
\end{abstract}

Keywords: Poti river, remote sensing, water quality.

\section{Recuperação e mapeamento da concentração de clorofila-a a partir de imagens do Sentinel-2 em um rio urbano na região semiárida do Brasil}

\section{RESUMO}

A região da foz do rio Poti experimentou nos últimos anos impactos ambientais que resultaram na mudança da sua paisagem na estação seca, destacando-se a eutrofização e a 
proliferação de fitoplâncton, algas, cianobactérias e plantas aquáticas. Considerando os aspectos relacionados ao monitoramento da qualidade da água na região semiárida do Brasil a partir do sensoriamento remoto, este estudo teve como objetivo avaliar o desempenho dos dados do satélite Sentinel-2A, na recuperação da concentração de clorofila-a no rio Poti em Teresina, Piauí, Brasil. A metodologia de recuperação e mapeamento da concentração de clorofila-a envolveu o estudo da reflectância da superfície da água nas imagens Sentinel-2A e a respectiva correlação com dados in situ de clorofila-a, coletados em pontos de monitoramento, durante os anos de 2016 e 2017. Os resultados gerados pelas equações Chl-1, Ha et al., (2017), Chl-2, Page et al., (2018), e Chl-3, Kuhn et al., (2019), mostram a necessidade de uma calibração dos modelos utilizados aos componentes das águas do rio Poti. No entanto, o algoritmo empírico Chl-2 mostra que uma correlação foi estabelecida para identificar a variação espaço-temporal das concentrações de clorofila-a ao longo do rio Poti de maneira ampla e não mais pontual. A distribuição espacial desse pigmento nos mapas oriundos do Sentinel-2A é consistente com o padrão de ocorrência determinado pelos dados in situ. Portanto, o sensor MSI provou ser uma ferramenta adequada para a recuperação e monitoramento da concentração de clorofila-a ao longo do rio Poti.

Palavras-chave: qualidade da água, rio Poti, sensoriamento remoto.

\section{INTRODUCTION}

Disorderly development in large urban centres, devoid of any planning and with increasing levels of environmental degradation, drastically affects water availability and especially its quality (Vargas et al., 2018). The quality of the river water is affected by factors such as the increase of domestic and industrial pollutants that favour the eutrophication of the river water. The eutrophication that can lead to the death of aquatic fauna and flora, turning the water unfit for consumption and other uses (Esteves, 2011; Jorge and Lobo, 2019).

Water-quality monitoring is a challenging process as data collection is insufficient or nonexistent for most bodies of water. Punctual samples do not always portray the dynamics of water constituents, because the river is a highly dynamic lotic ecosystem that requires the collection of a large number of quality parameters to understand spatiotemporal variations and monitor changes (Prasad et al., 2018; Kuhn et al., 2019; Martins, 2019). In contrast, some authors have adopted an efficient approach that integrates diverse in situ data with remote sensing images to monitor the factors that affect water quality and understand the limnological processes, because satellite imagery provide the synoptic, continuous and long-term observation (Ha et al., 2017; Pinardi et al., 2018; Martins, 2019).

The European Space Agency (ESA) has launched the mission Sentinel-2 with two identical satellites. The MultiSpectral Instrument (MSI) onboard the satellites is a 13-band passive optical sensor in a $20.6^{\circ}$ orbital field of instrumental view. These features, in addition to a 10 $\mathrm{m}$ spatial resolution and five-day high temporal resolution, make the MSI sensor a suitable instrument for the retrieval of biophysical parameters in inland waters compared to other satellite missions designed for such applications as Landsat-8 / OLI, Sentinel-3 / OLCI, Aqua / MODIS (ESA, 2019; Pinardi et al., 2018; Pereira-Sandoval et al., 2019).

Studies on the use of Sentinel-2A images in the retrieval and mapping of chlorophyll-a focus on a limited number of band ratio empirical algorithms. These models are based on statistical relationships between in situ measurements of water constituents and radiometric data from the satellite sensor, which provide the best correlation between reflectance data and the concentration of optically active water constituents at different wavelengths (Ogashawara et $a l ., 2017)$. The commonly used two band-ratio algorithms are based on the ratios of the blue $(440$ and $510 \mathrm{~nm})$ and green regions (550 and $555 \mathrm{~nm})$, of the red $(670$ and $675 \mathrm{~nm})$ and near 
infrared (NIR) regions (685 and $710 \mathrm{~nm})$, and of the green (550 and $555 \mathrm{~nm}$ ) and red regions (670 and $675 \mathrm{~nm}$ ) (Mouw et al., 2015; Toming et al., 2016; Ha et al., 2017).

In the semiarid region of Brazil, in the city of Teresina, in the state of Piaui, the urban riverbed of the Poti River has experienced intense environmental impacts in recent years, leading to changes in its landscape in the dry season, highlighting eutrophication and the proliferation of phytoplankton, algae, cyanobacteria and mainly from aquatic plants (Costa, 2014; Santos, 2017). The Sanitation Laboratory at the Federal University of Piaui has estimated chlorophyll-a concentration in punctual samples of the Poti River from laboratory analyses in 2016 and 2017. However, this sampling is a costly and low-temporal frequency procedure. The application of remote sensing can monitor large extensions of the Poti River over a long period and with a high temporal frequency, reducing efforts and resources, because six Sentinel-2 images are acquired monthly in the study area.

In this context, this study evaluated the performance of the Sentinel-2A satellite data in the retrieval of chlorophyll-a concentrations in Poti River in Teresina, Piaui, Brazil. This is the first attempt to use remote-sensing techniques to monitor the spatial and temporal variability of water quality parameters in order to support the decision-making process, regarding preventive and corrective environmental management of the intense environmental impacts that occur in the Poti River, mainly in the dry season.

\section{MATERIALS AND METHODS}

\subsection{Study area}

The study area, as shown in Figure 1, corresponds to the $36.8 \mathrm{~km}$ urban stretch along the Poti River, located in the municipality of Teresina, which is the largest city and the capital city of the state of Piaui, Brazil. This section of the river was chosen due to the location of the water quality monitoring sample points that have been carried out by the Sanitation Laboratory at the Federal University of Piaui.
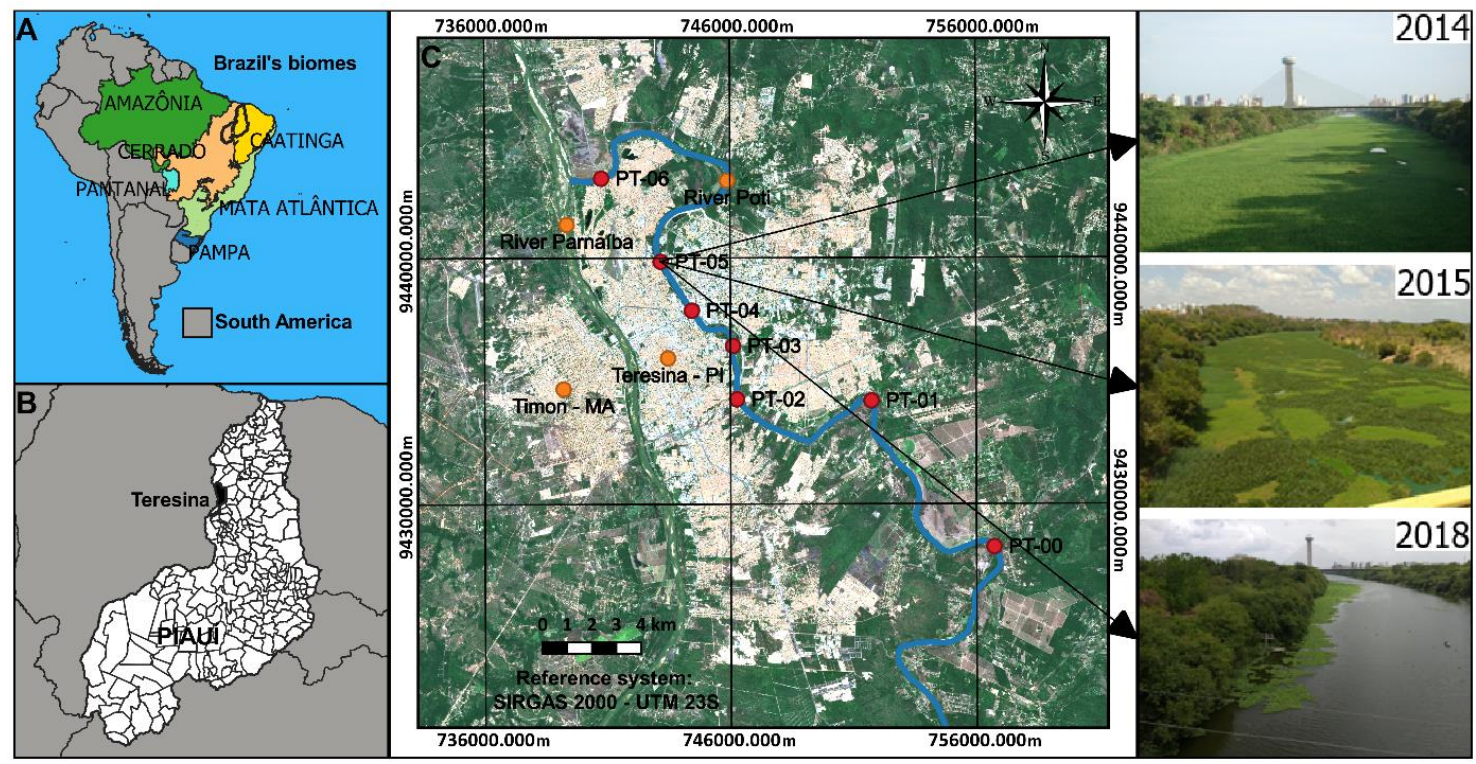

Figure 1. Study area: A) location of the study area in the context of Brazil's biomes (Brasil, 2017); B) location of Teresina in the state of Piaui; and, C) In the image Sentinel-2A L2A, acquired in August 2019 (ESA, 2019), shows the urban stretch of the Poti River in Teresina, with the location of the seven chlorophyll-a concentration monitoring points. From point PT-05, the environmental impacts occurred in 2014 (Costa, 2014) and 2018, upstream and 2015, downstream are observed. 
Alessandro Rhadamek Alves Pereira et al.

The Poti River originates in the state of Ceara, in the city of Algodoes, and empties into the River Parnaiba, in Teresina. River Poti's mouth flows around $1.3 \mathrm{~m}^{3} \mathrm{~s}-1$, on average in the driest quarter. The studied area has an approximate area of $3.7 \mathrm{~km}^{2}$ and an average width of 100 $\mathrm{m}$ in the rainy season and, during the dry season, it can be reduced to a few meters wide and a few centimetres deep in some places (Mendes-Câmara, 2011).

The region is in the transition zone between the Cerrado and Caatinga biomes, in which the predominant natural vegetation is mixed forests that are being replaced by areas of agriculture and degraded vegetation (Espindola et al., 2017). The climate of the region is characterized as tropical equatorial zone, warm, semiarid, with a dry season from July to November and a rainy season from January to April, an average annual temperature and precipitation of $27.4^{\circ} \mathrm{C}$ and $1.325 \mathrm{~mm}$, in that order (IBGE, 2015; INMET, 2018). In the last four decades, Teresina, with $1,391.046 \mathrm{~km}^{2}$ of area, has suffered high rates of urban expansion (IBGE, 2017). The city urbanization tendencies show that urban expansion has been larger than the population growth, causing problems related to the occupation of flood regions in the confluence of the Parnaiba and Poti Rivers, the contamination of the rivers themselves, the increase of the traffic, the increase of air pollution, lack of adequate housing and general infrastructure in peripheral areas (Espindola et al., 2017). It is noteworthy that Teresina has only $61.6 \%$ of households with adequate sanitation (IBGE, 2017).

\subsection{Remote sensing data acquisition and preprocessing}

In this study, the remote-sensing data has been obtained by the Sentinel-2A satellite, available on the Copernicus Open Access Hub web platform (ESA, 2019). The images have the size, spatial and radiometric resolution of $100 \mathrm{~km} \times 100 \mathrm{~km}, 10 \mathrm{~m}, 20 \mathrm{~m}$ and $60 \mathrm{~m}$, and $12 \mathrm{bits}$, respectively. The Level-1C (L1C) product downloaded is pre-processed, orthorectified, georeferenced to the Universal Transverse Mercator projection using the World Geodetic System 84 datum, and radiometrically calibrated for top-of-reflectance atmosphere (ESA, 2018). The atmospheric correction was processed in the downloaded images using the Sen2Cor2.5.5 processor, available in the Sentinel Application Platform (SNAP-6) program toolbox, resulting in Level-2A (L2A) product, radiometrically calibrated for bottom-of-atmosphere reflectance. As the algorithm used in the correction described above processes bands of different spatial resolutions, the images were resampled to $20 \mathrm{~m}$ by the tool (ESA, 2018). The specifications of Sentinel-2A bands used in this study are presented in Table 1 (ESA, 2018; SINERGISE, 2018).

Table 1. Bands specifications for Sentinel-2A.

\begin{tabular}{|c|c|c|c|c|}
\hline Band & $\begin{array}{l}\text { Central } \\
\text { wavelength } \\
(\mathbf{n m})\end{array}$ & $\begin{array}{l}\text { Wavelength } \\
(\mathbf{n m})\end{array}$ & $\begin{array}{l}\text { Spatial } \\
\text { resolution } \\
\quad(\mathbf{m})\end{array}$ & Capabilities \\
\hline $\begin{array}{l}\text { B02 } \\
\text { Blue }\end{array}$ & 492.4 & $458-523$ & 10 & $\begin{array}{l}\text { Is useful for soil and vegetation } \\
\text { discrimination forest type mapping; Is } \\
\text { absorbed by chlorophyll }\end{array}$ \\
\hline $\begin{array}{c}\text { B03 } \\
\text { Green }\end{array}$ & 559.8 & $543-578$ & 10 & $\begin{array}{l}\text { Gives excellent contrast between clear and } \\
\text { turbid water, and fairly well penetrates clear } \\
\text { water }\end{array}$ \\
\hline B04 Red & 664.6 & $650-680$ & 10 & $\begin{array}{l}\text { Reflects well from dead foliage and is useful } \\
\text { for identifying vegetation types, soils and } \\
\text { urban features }\end{array}$ \\
\hline $\begin{array}{l}\text { B05 Red } \\
\text { edge } 1\end{array}$ & 704.1 & $698-713$ & 20 & For classifying the vegetation \\
\hline
\end{tabular}


The multispectral images have been selected considering the dates available from 2016, the Sentinel-2A satellite launch period until the end of 2017 according field data, following the criteria of cloud-free in study area, totalling a set of eight scenes, in the orbit 138, with the subsequent acquisition dates: August $15^{\text {th }}, 2016$; September $24^{\text {th }}, 2016$; October $14^{\text {th }}, 2016$;

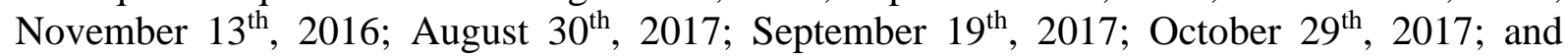
November $18^{\text {th }}, 2017$.

\subsection{Field Data}

During 2016 and 2017, the Sanitation Laboratory sampled chlorophyll-a concentrations at seven monitoring points shown in Figure 1 monthly. The reference standards for the monitoring of bodies of water are set out in National Environmental Council Resolution No. 357 (CONAMA, 2005) and in the National Water Agency's National Sample Collection and Preservation Guide (ANA, 2011). The chlorophyll-a were obtained from water samples by the spectrophotometric analysis using a Hach DR 2800 Spectrophotometer. Samples were filtered, extracted and calculated according to colorimetric method (Marker et al., 1980). From a total of 168 samples available, 56 samples were used corresponding to the dry season. Field data campaigns were conducted on August 17 $7^{\text {th }}, 2016$; September $21^{\text {st }}, 2016$; October $26^{\text {th }}, 2016$; November 23 $3^{\text {rd }}, 2016$; August $18^{\text {th }}, 2017$; September $16^{\text {th }}, 2017$; October $28^{\text {th }}, 2017$; and November $25^{\text {th }}, 2017$.

Considering that the field data sampling collecting date did not agree with the dates that Sentinel-2A overpassed the study area, we analysed all time windows available in the dry season, because it is the critical period during which eutrophication and the proliferation of phytoplankton, algae, cyanobacteria and aquatic plants occur. The number of match-ups along the period under study: 1 with one-day difference, 1 with two-days difference, 2 with threedays difference, 1 with seven-days difference, 1 with ten-days difference and 2 with twelvedays difference.

\subsection{Chlorophyll-a concentration retrieval algorithms}

A variety of empirical algorithms have been developed and used to retrieve chlorophyll-a concentration in inland waters, where the spectral reflectance curves of waters with different chlorophyll-a concentrations are characterized by high absorptions in the blue and red bands and high reflectance in the green and red edge bands (Matthews, 2017; Ogashawara et al., 2017). The choice of the algorithms was based on a literature review in which the band ratio empirical algorithms found in Ha et al., 2017 (Chla-1: Equation 1), Page et al., 2018 (Chla-2: Equation 2) and Kuhn et al., 2019 (Chla-3: Equation 3) were selected. These algorithms include the green to blue band ratios and those including the red band and red edge band (Ha et al., 2017; Page et al., 2018; Kuhn et al., 2019). They were routinely applied to Sentinel-2A data and obtained the best performances in retrieval chlorophyll-a in lentic and lotic inland waters from regions with similar geographical and climatic features as those found in the study area.

$$
\begin{aligned}
& \text { Chla }=0.80\left(\exp \left(0.35\left(\frac{B 03}{B 04}\right)\right)\right) \\
& \text { Chla }=14.039+86.115\left(\frac{\rho_{r c}(B 05)-\rho_{r c}(B 04)}{\rho_{r c}(B 05)+\rho_{r c}(B 04)}\right)+194.325\left(\frac{\rho_{r c}(B 05)-\rho_{r c}(B 04)}{\rho_{r c}(B 05)+\rho_{r c}(B 04)}\right)^{2} \\
& \log _{10}(\operatorname{chla})=0.2412-2.0546\left(\log _{10}\left(\frac{R_{r s}\left(\lambda_{B 02)}\right.}{R_{r s} \lambda_{(B 03)}}\right)\right)+1.1776\left(\log _{10}\left(\frac{R_{r s}\left(\lambda_{B 02)}\right.}{R_{r s} \lambda_{(B 03)}}\right)\right)^{2}- \\
& 0.5538\left(\log _{10}\left(\frac{R_{r s}\left(\lambda_{B 02)}\right.}{R_{r s} \lambda_{(B 03)}}\right)\right)^{3}+0.4570\left(\log _{10}\left(\frac{R_{r s}\left(\lambda_{B 02)}\right.}{R_{r s} \lambda_{(B 03)}}\right)\right)^{4}
\end{aligned}
$$


In this understanding, the following steps were performed in QGIS Desktop 3.4.5 software: i) Calculation of chlorophyll-a concentration as a function of the Chla-1, Chla-2 and Chla-3 equations in Sentinel-2A / L2A images (satellite-derived). The Sentinel-2A band selection (Table 1) has followed the proximity wavelength criteria closest to that defined by each empirical algorithm; ii) Listing of chlorophyll-a values at the seven monitoring points.

Discrepancies between chlorophyll-a concentrations of punctual data, in situ (Chla-is) and satellite-derived (Chl-1, Chl-2, Chl-3), were quantified using statistical metrics, often intended for evaluation of remote-sensing algorithms, which in this case include the Pearson squared correlation or coefficient of determination $\left(\mathrm{R}^{2}\right)$, the Root Mean Square Error (RMSE), and the Bias (Ha et al., 2017; Page et al., 2018; Kuhn et al., 2019). All data were analyzed using R 3.6.1 and Past 3.24 statistical softwares.

The $\mathrm{R}^{2}$ metric represents the linear consistency between the observations and the proportion of the variation explained by the linear regression, the RMSE measures the precision of the combinations and the absolute difference, which is sensitive to the extreme values, and the Bias determines the underestimation or overestimation of the calculated data, compared to field-measured data (Qin et al., 2017; Ansper and Alikas, 2019). A high $\mathrm{R}^{2}$ value indicates a high degree of correlation between in situ observations and Sentinel-2A, while a low RMSE value indicates that Sentinel-2A observations resemble well with in situ observations, and a value close to zero for Bias suggests that there is no systematic underestimation or overestimation of Sentinel-2 and in situ data (Qin et al., 2017).

\section{RESULTS AND DISCUSSION}

\subsection{Comparison of chlorophyll-a concentrations}

Table 2 shows the descriptive statistics of in situ chlorophyll-a (Chla-is) punctual concentration levels during the sampling period. In the Poti River, spatial variability is represented by the variation in the average concentrations of Chla-is, while the high standard deviation in the concentration levels of Chla-is indicates temporal variability.

Table 2. Descriptive statistics of chlorophyll-a in situ punctual concentration ( $\left.\mathrm{mg} \mathrm{m}^{3}-1\right)$ in 2016 and 2017.

\begin{tabular}{cccccc}
\hline Point / Year & Mean & Standard deviation & Coefficient of Variation & Minimum & Maximum \\
\hline PT-00/16 & 17.75 & 15.68 & 0.88 & 5.46 & 38.22 \\
PT-01/16 & 31.40 & 26.14 & 0.83 & 10.92 & 65.52 \\
PT-02/16 & 32.76 & 31.21 & 0.95 & 5.46 & 76.44 \\
PT-03/16 & 23.21 & 8.19 & 0.35 & 16.38 & 32.76 \\
PT-04/16 & 39.59 & 21.09 & 0.53 & 27.30 & 70.98 \\
PT-05/16 & 28.67 & 16.90 & 0.59 & 5.46 & 43.68 \\
PT-06/16 & 27.30 & 24.82 & 0.91 & 5.46 & 60.06 \\
PT-00/17 & 5.18 & 2.07 & 0.40 & 4.14 & 8.29 \\
PT-01/17 & 10.36 & 7.94 & 0.77 & 4.14 & 20.72 \\
PT-02/17 & 15.54 & 12.37 & 0.80 & 4.14 & 33.15 \\
PT-03/17 & 9.32 & 7.84 & 0.84 & 4.14 & 20.72 \\
PT-04/17 & 9.32 & 7.84 & 0.84 & 4.14 & 20.72 \\
PT-05/17 & 10.36 & 4.14 & 0.40 & 8.29 & 16.58 \\
PT-06/17 & 11.40 & 7.08 & 0.62 & 4.14 & 20.72 \\
\hline
\end{tabular}


From the monthly in situ samples of chlorophyll-a, the average results obtained in 2016 were $28.67 \mathrm{mg} \mathrm{m}^{3}-1$, ranging from $5.46 \mathrm{mg} \mathrm{m}^{3}-1$, recorded at PT-00, to $76.44 \mathrm{mg} \mathrm{m}^{3}-1$, read at PT-02, both in August. In 2017, the average chlorophyll-a count was $10.21 \mathrm{mg} \mathrm{m}^{3}-1$, also varying in August at the same points, between $4.14 \mathrm{mg} \mathrm{m}^{3}-1$ and $33.15 \mathrm{mg} \mathrm{m}^{3}-1$, respectively. According to the data, annually the concentration of chlorophyll-a increases from August to December, peaking in November, and in 2017 there was a reduction of $36 \%$ in the concentration of chlorophyll-a in the study area. These results show a large spatiotemporal variation of chlorophyll-a in the dry season, depending on the location of the collection points, where the points that indicate the lowest and highest recurrent chlorophyll-a concentrations are PT-00 and PT-02.

The influence of factors such as incipient environmental management, occupation of river margins, existence of clandestine connections of raw sewage in the rain drainage and the high evaporation of water, have contributed to the alteration of the limnological characteristics of the Poti River (Oliveira and Silva, 2014; Oliveira Filho and Lima Neto, 2018). In addition, in the dry season, the reduction in flow, width and depth favour the formation of natural barriers, such as meandering curves, rocky outcrops, alluvial deposits of pebbles to sands and river islands, cause the damming of Poti River waters (Lima and Augustin, 2014). From this perspective, natural and artificial barriers, in addition to the land-use change, are the most important structural determinants for the modification of the limnological characteristics of a watershed, as they create a lentic mosaic macrosystem, very different from the original lotic condition, favourable to the processes of eutrophication (Debastiani Júnior et al., 2016). These concentrations can be explained by the location of these points, as PT-00 is located in the leastinhabited region, with preserved riparian forest and without contributions from domestic and industrial effluents, while PT-02 is located at $850 \mathrm{~m}$ downstream from the Alegria Sewage Treatment Plant (Mendes-Câmara, 2011).

Subsequently, the processing of the Chl-1, Chl-2 and Chl-3 equations was performed on Sentinel-2A / L2A images obtaining the values of chlorophyll-a at seven points.

Considering that these algorithms also tend to vary in performance, because depending on the optical properties of the river and chlorophyll-a, temperature, nutrients and light may introduce classification errors, the performance of the applied algorithms was analyzed punctually in Sentinel-2 images available in the dry period. In total, four values of chlorophylla were used for each sampling point. The performances of the algorithms for the Poti River are summarized in Table 3.

Considering a moderate correlation, with $\mathrm{R}^{2}$ values equal or higher than 0.50 , between the results of punctual quantitative agreement between in situ data and values obtained with each equation, overall, the empirical algorithm Chl-2, with seven values, obtained the best point performance compared to the algorithms Chl-1, with six values, and Chl-3, with four values. Therefore, according to this data, the relation between the bands B04 and B05 most indicated the retrieval of chlorophyll-a in the Poti River.

In this sense, considering the Equation Chl-2, by Page et al. (2018), Figure 2 shows the graphs of the dynamics of the chlorophyll-a in situ (Chla-is) and satellite-derived (Chl-2) for 2016 (samples 1-28) and 2017 (samples 29-56). In the set of 56 samples, the Chl-2 algorithm shows an overestimation of concentrations, as indicated by Bias, and follows the tendency of chlorophyll-a to occur as pointed out by the in situ data. However, it is possible to observe the performance of the algorithm at different collection points along the river and realise that it can estimate the variation of chlorophyll-a concentration broadly and not more punctual.

\subsection{Mapping of chlorophyll-a concentrations}

The mapping of chlorophyll-a concentrations was performed using the QGIS Desktop 3.4.5; when a clipping was generated referring to the study area, in the images resulting from 
each calculated equation it was possible to spatially verify the occurrence and distribution of chlorophyll-a along the Poti River in the mentioned biennium.

Maps derived from Sentinel-2A-L2A show details of the spatial variation of chlorophylla concentration, allowing easy identification of areas with high or no chlorophyll-a concentrations, and show that there is a common pattern between estimated and in situ data. At the same time, regardless of the algorithm used, the maps always show the stretch from Point PT-04 to the mouth of the Poti River, approximately $16 \mathrm{~km}$ long, as the area with a high concentrations of chlorophyll-a.

Table 3. Comparison by point between estimated and in situ chlorophyll-a concentration ( $\left.\mathrm{mg} \mathrm{m}^{3}-1\right)$ in 2016 and 2017.

\begin{tabular}{cccccccccc}
\hline \multirow{2}{*}{ Point / Year } & \multicolumn{3}{c}{ Chl-1 } & \multicolumn{3}{c}{ Chl-2 } & \multicolumn{3}{c}{ Chl-3 } \\
\cline { 2 - 10 } & R $^{2}$ & RMSE & Bias & R $^{2}$ & RMSE & Bias & R $^{2}$ & RMSE & Bias \\
\hline PT-00/16 & 0.17 & 21.34 & -16.51 & 0.54 & 16.26 & 0.68 & 0.41 & 21.35 & -16.57 \\
PT-01/16 & 0.00 & 37.70 & -30.15 & 0.25 & 28.23 & 1.70 & 0.73 & 38.13 & -30.70 \\
PT-02/16 & 0.06 & 41.45 & -31.41 & 0.03 & 30.10 & 6.17 & 0.59 & 41.83 & -31.87 \\
PT-03/16 & 0.75 & 22.97 & -21.87 & 0.98 & 23.29 & 23.25 & 0.16 & 23.43 & -22.30 \\
PT-04/16 & 0.54 & 42.32 & -38.14 & 0.45 & 44.40 & 27.15 & 0.25 & 42.74 & -38.58 \\
PT-05/16 & 0.65 & 30.93 & -27.15 & 0.52 & 65.05 & 45.86 & 0.49 & 31.38 & -27.68 \\
PT-06/16 & 0.01 & 33.63 & -25.85 & 0.01 & 38.39 & 24.74 & 0.01 & 34.08 & -26.43 \\
PT-00/17 & 0.96 & 4.37 & -3.95 & 1.00 & 7.96 & 6.64 & 0.94 & 4.80 & -4.42 \\
PT-01/17 & 0.15 & 11.43 & -9.12 & 0.20 & 14.80 & 13.35 & 0.46 & 11.78 & -9.65 \\
PT-02/17 & 0.05 & 17.85 & -14.27 & 0.67 & 21.15 & 11.34 & 0.00 & 18.28 & -14.80 \\
PT-03/17 & 0.39 & 10.51 & -8.04 & 0.22 & 20.70 & 19.38 & 0.26 & 10.93 & -8.54 \\
PT-04/17 & 0.85 & 10.45 & -8.02 & 0.91 & 23.43 & 22.42 & 0.48 & 10.76 & -8.41 \\
PT-05/17 & 0.79 & 9.70 & -9.03 & 0.95 & 27.34 & 26.91 & 0.01 & 10.20 & -9.55 \\
PT-06/17 & 0.29 & 11.83 & -10.07 & 0.07 & 36.50 & 29.30 & 0.54 & 12.45 & -10.74 \\
\hline
\end{tabular}

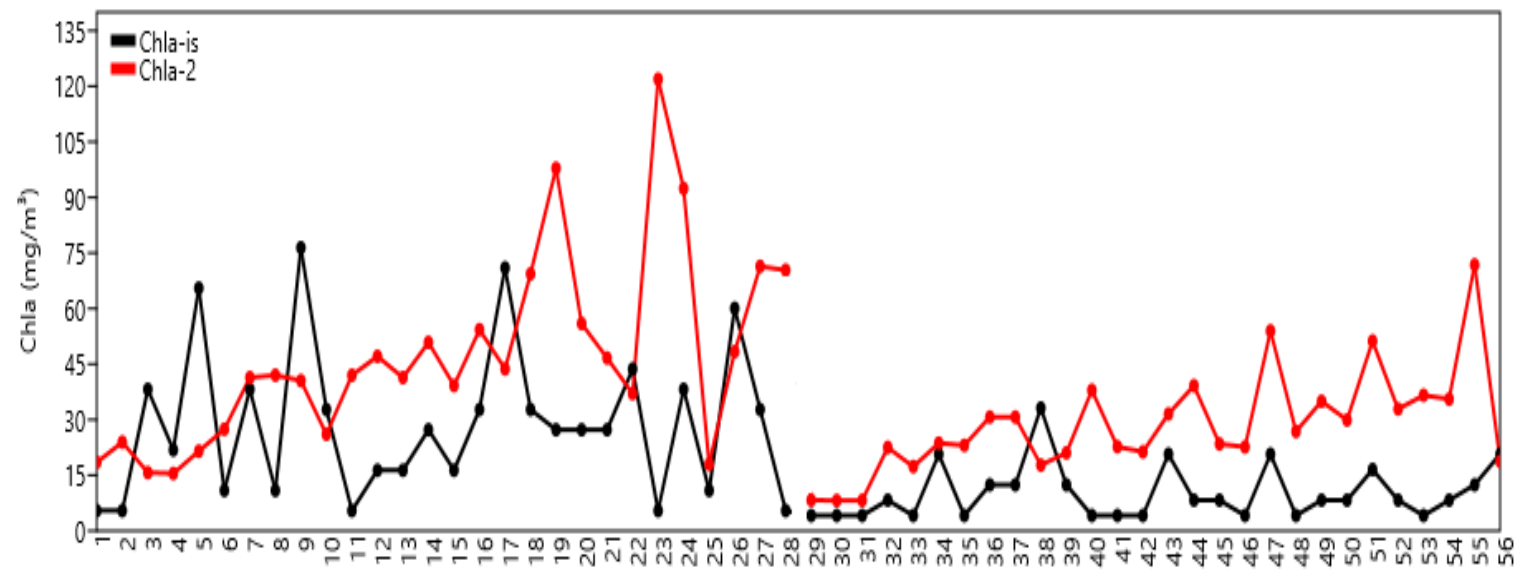

Figure 2. Comparison between the Chla-2 and Chla-is indices in 2016 and 2017.

Figure 3 shows the change in chlorophyll-a concentration at the beginning of the dry seasons of 2016 and 2017, calculated with data from the Chl-2 algorithm (Page et al., 2018), with emphasis on the section of Point PT-04 to the mouth of the Poti River in the months of 
August until November of each year. As can be seen in this figure, the high concentration of chlorophyll-a corresponds to red.

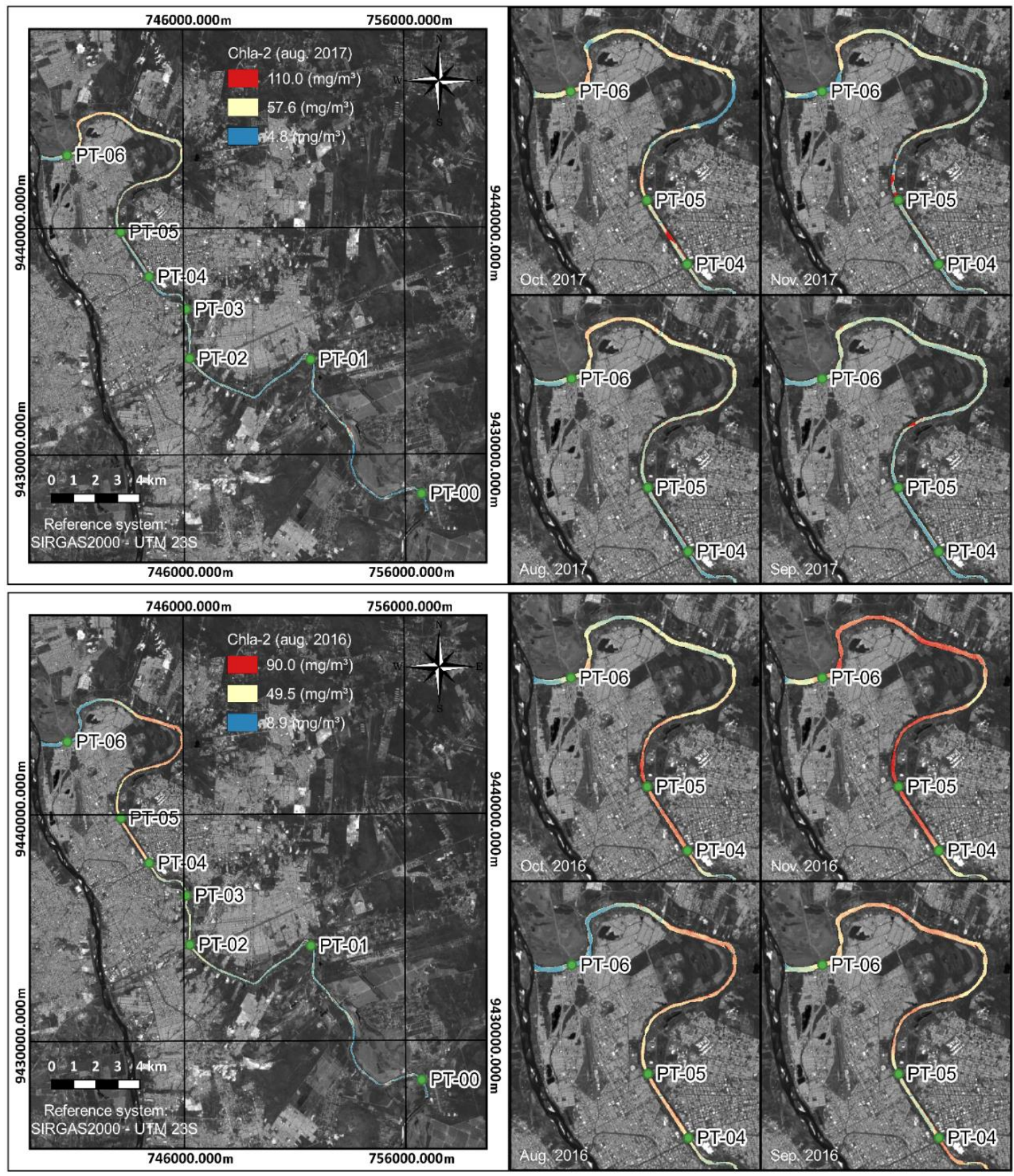

Figure 3. Spatial distribution of chlorophyll-a concentration from August to November 2016 and from August to November 2017.

\section{CONCLUSIONS}

This study is the first attempt to evaluate the use of Sentinel-2 in Poti River remote sensing. The results show that Sentinel-2 images have great potential for urban river remote sensing, as we were able to retrieve and map chlorophyll-a concentrations by means of routinely used empirical algorithms.

The results generated by the Chl-1, Ha et al. (2017), Chl-2, Page et al. (2018), and Chl-3, Kuhn et al. (2019) equations show the need for calibration of the models used to simulate the

\section{IPABH}

Rev. Ambient. Água vol. 15 n. 2, e2488 - Taubaté 2020 
Poti River water components. Considering a moderate correlation between the results of punctual quantitative agreement between the in situ data and the values obtained with each equation, the empirical algorithm Chl-2 obtained a better punctual performance than the algorithms Chl-1 and Chl-3.

The empirical algorithm Chl-2 shows a correlation has been established to identify the spatiotemporal variation of chlorophyll-a concentration along the Poti River broadly and not more punctually. The spatiotemporal distribution of chlorophyll-a in maps from Sentinel-2A images are consistent with the pattern of occurrence determined by the in situ data. Therefore, the MSI sensor proved to be a tool suitable for the detection and monitoring of chlorophyll-a concentration along the Poti River.

In addition, it is recommended that a chlorophyll-a concentration monitoring system be implemented using a calibrated algorithm for the Poti River optical properties and Sentinel-2 data in order to improve the environmental management of the river. To enable the monitoring of water quality in urban rivers, especially in the tropical semiarid region of Brazil is a contribution to the conservation of the environment and the sustainable management of this water resource, as it will permit the verification of current and possible future conditions of eventual environmental, social and economic impacts.

\section{REFERENCES}

ANA. Guia nacional de coleta e preservação de amostras: água, sedimento, comunidades aquáticas e efluentes líquidos. São Paulo: CETESB; Brasília: ANA, 2011. 326p. Available at: http://arquivos.ana.gov.br/institucional/sge/CEDOC/Catalogo/2012/GuiaNacionalDeCol eta.pdf Access: 05 oct. 2017.

ANSPER, A.; ALIKAS, K. Retrieval of chlorophyll a from Sentinel-2 MSI data for the European Union Water Framework Directive reporting purposes. Remote Sensing, v. 11, n. 1, p. 64, 2019. https://doi.org/10.3390/rs11010064

BRASIL. Ministério do Meio Ambiente. Biomas. Brasília, 2017. Available at: http://mapas.mma.gov.br/i3geo/datadownload.htm. Access: 03 May 2019.

CONAMA (Brasil). Resolução n 357 de 17 de março de 2005. Dispõe sobre a classificação dos corpos de água e diretrizes ambientais para o seu enquadramento, bem como estabelece as condições e padrões de lançamento de efluentes, e dá outras providências. Diário Oficial [da] União: seção 1, Brasília, DF, n. 053, p. 58-63, 18 mar. 2005.

COSTA, C. Aguapés são retirados do Rio Poti em Teresina após ação do MPF. G1 PI, Teresina, 10 de fevereiro de 2014. Available at: http://g1.globo.com/pi/piaui/noticia/2014/02/aposquatro-meses-da-acao-do-mpf-aguapes-serao-retirados-do-rio-poti.html. Access: 03 nov. 2014.

DEBASTIANI JÚNIOR, J. R.; NALIATO, D. A. O.; PERBICHE-NEVES, G.; NOGUEIRA, M. G. Fluvial lateral environments in Río de La Plata basin: effects of hydropower damming and eutrophication. Acta Limnologica Brasiliensia, v. 28, e26, 2016. http://dx.doi.org/10.1590/s2179-975x5516

ESA. Sentinel-2 Products Specification Document. France: Thales Alenia Space, 2018, 510p. Available at: https://sentinel.esa.int/documents/247904/685211/Sentinel-2-ProductsSpecification-Document. Access: 30 Aug. 2018.

ESA. Copernicus Open Access Hub. 2019. Available at: https://scihub.copernicus.eu/dhus/\#/home. Access: 15 Aug. 2019. 
ESPINDOLA, G. M.; CARNEIRO, E. L. N. C.; FAÇANHA, A. C. Four decades of urban sprawl land population growth in Teresina, Brazil. Applied Geography, v. 79, p. 73-83, 2017. https://doi.org/10.1016/j.apgeog.2016.12.018

ESTEVES, F. de A. Fundamentos de limnologia. 3. ed. Rio de Janeiro: Interciência, 2011. $790 \mathrm{p}$.

HA, N. T. T.; THAO, N. T. P.; KOIKE, K.; NHUAN, M. T. Selecting the best band ratio to estimate chlorophyll-a concentration in a tropical freshwater lake using Sentinel 2A images from a case study of lake Ba Be (Northern Vietnam). International Journal of Geo-Information, v. 6, p. 290, 2017. https://doi.org/10.3390/ijgi6090290

IBGE. Clima do Brasil 1:500.000. Brasília, 2015. Available at: http://dados.gov.br/dataset/cren_climadobrasil_5000. Access: 14 Apr. 2018.

IBGE. Brasil/Piauí/Teresina. Brasília, 2017. Available at: https://cidades.ibge.gov.br/brasil/pi/teresina/panorama. Access: 08 Feb. 2019.

INMET. Normais Climatológicas do Brasil 1981-2010. Brasília, 2018. Available at: http://www.inmet.gov.br/portal/index.php?r=clima/normaisClimatologicas. Access: 14 Apr. 2018.

JORGE, D. S. F.; LOBO, F. L. Aplicações do sensoriamento remoto em águas continentais estudos de caso. In: BARBOSA, C. C. F.; NOVO, E. M. L. M.; MARTINS, V. S. (Eds.). Introdução ao sensoriamento remoto de sistemas aquáticos: princípios e aplicações. 1. ed. São José dos Campos, SP: INPE, 2019. p. 136-152.

KUHN, C.; VALERIO, A. M.; WARD, N.; LOKEN, L.; SAWAKUCHI, H. O.; KAMPEL, M.; RICHEY, J.; STADLER, P.; CRAWFORD, J.; STRIEGL, R.; VERMOTE, E.; PAHLEVAN, N.; BUTMAN, D. Performance of Landsat-8 and Sentinel-2 surface reflectance products for river remote sensing retrievals of chlorophyll-a and turbidity. Remote Sensing of Environment, v. 224, p. 104-118, 2019. https://doi.org/10.1016/j.rse.2019.01.023

LIMA, I. M. M. F.; AUGUSTIN, C. H. R. R. Bacia hidrográfica do rio Poti: dinâmica e morfologia do canal principal no trecho do baixo curso. In: SIMPÓSIO NACIONAL DE GEOMORFOLOGIA, 10., 2014, Manaus. Anais[...] Manaus: SINAGEO; UFAM, 2014. v. 1 .

MARKER, A. F. H.; NUSCH, E. A.; RAI, H.; RIEMANN, B. The measurement of photosynthetic pigments in freshwaters and standardization of methods: conclusions and recommendations. Ergebnisse der Limnologie, v. 14, p. 91-106, 1980.

MARTINS, V. S. Sistemas orbitais para monitoramento de ambientes aquáticos. In: BARBOSA, C. C. F.; NOVO, E. M. L. M.; MARTINS, V. S. (Eds.). Introdução ao sensoriamento remoto de sistemas aquáticos: princípios e aplicações. 1. ed. São José dos Campos, SP: INPE, 2019. p. 107-135.

MATTHEWS, M. W. Bio-optical modeling of phytoplankton chlorophyll-a. In: MISHRA, D. R.; OGASHAWARA, I.; GITELSON, A. A. (Eds.). Bio-optical modeling and remote sensing of inland waters. 1. ed. Amsterdam: Elsevier, 2017. p. 157-188. https://doi.org/10.1016/B978-0-12-804644-9.00001-X

MENDES-CÂMARA, F. M. Avaliação da qualidade da água do rio Poti na cidade de Teresina, Piauí. 2011. 162f. Tese (Doutor em Geografia) - Instituto de Geociências e Ciências Exatas, Universidade Estadual Paulista, Rio Claro, 2011. 
MOUW, C. B.; GREB, S.; AURIN, D.; DIGIACOMO, P. M.; LEE, Z.; TWARDOWSKI, M.; BINDING, C.; HU, C.; MA, R.; MOORE, T.; MOSES, W.; CRAIG, S. E. Aquatic color radiometry remote sensing of coastal and inland waters: Challenges and recommendations for future satellite missions. Remote Sensing of Environment, v. 160, p. 15-30, 2015. https://doi.org/10.1016/j.rse.2015.02.001

OGASHAWARA, I.; MISHRA, D. R.; GITELSON, A. A. Remote sensing of inland waters: background and current state-of-the-art. In: MISHRA, D. R.; OGASHAWARA, I.; GITELSON, A. A. (Eds.). Bio-optical modeling and remote sensing of inland waters. 1. ed. Amsterdam: Elsevier, 2017. p. 1-24. https://doi.org/10.1016/B978-0-12-8046449.00001-X

OLIVEIRA, L. N. de.; SILVA, C. E. da. Qualidade da água do rio poti e suas implicações para atividade de lazer em Teresina-PI. Revista Equador, v. 3, n. 1, p. 128-147, 2014.

OLIVEIRA FILHO, A. A. de.; LIMA NETO, I. E. Modelagem da qualidade da água do rio Poti em Teresina (PI). Engenharia Sanitária Ambiental, v.23, n.1, 2018. http://dx.doi.org/10.1590/s1413-41522017142354

PAGE, B. P.; KUMAR, A.; MISHRA, D. R. A novel cross-satellite based assessment of the spatio-temporal development of a cyanobacterial harmful algal bloom. International Journal of Applied Earth Observation and Geoinformation, v. 66, p. 69-81, 2018. https://doi.org/10.1016/j.jag.2017.11.003

PEREIRA-SANDOVAL, M.; URREGO, E. P.; RUIZ-VERDÚ, A.; TENJO, C.; DELEGIDO, J.; SÒRIA-PERPINYÀ, X.; VICENTE, E.; SORIA, J.; MORENO, J. Calibration and validation of algorithms for the estimation of chlorophyll-a concentration and Secchi depth in inland waters with Sentinel-2. Limnetica, v. 38, n. 1, p. 471-487, 2019. https://dx.doi.org/10.23818/limn.38.27

PINARDI, M.; BRESCIANI, M.; VILLA, P.; CAZZANIGA, I.; LAINI, A.; TÓTH, V.; FADEL, A.; AUSTONI, M.; LAMI, A.; GIARDINO, C. Spatial and temporal dynamics of primary producers in shallow lakes as seen from space: Intra-annual observations from $\begin{array}{llllll}\text { Sentinel-2A. } & \text { Limnologica, } & \text { v. } & 72, & \text { p. } & 32-43,\end{array}$ https://doi.org/10.1016/j.limno.2018.08.002

PRASAD, S.; SALUJA, R.; J. K. GARG, J. K. Modeling chlorophyll-a and turbidity concentrations in river Ganga (India) using Landsat-8 OLI imagery. In: Earth Resources and Environmental Remote Sensing/GIS Applications, 8., 2017, Warsaw, Poland. SPIE Proceedings[...] Available at: https://doi.org/10.1117/12.2304034. Access: 14 Apr. 2018.

QIN, P.; SIMIS, S.G.H.; TILSTONE, G.H. Radiometric validation of atmospheric correction for MERIS in the Baltic Sea based on continuous observations from ships and AERONET-OC. Remote Sensing of Environment, v. 200, p. 263-280, 2017. https://doi.org/10.1016/j.rse.2017.08.024

SANTOS, L. Aguapés voltam a tomar conta da superfície do rio Poti. Portalodia, 07 Nov. 2017. Available at: https://www.portalodia.com/noticias/teresina/aguapes-voltam-atomar-conta-da-superficie-do-rio-poti-308858.html. Access: 05 Mar. 2018.

SINERGISE. Sentinel 2 EO products. Available at: https://www.sentinelhub.com/develop/documentation/eo_products/Sentinel2EOproduct. Access: $04 \mathrm{Sep}$. 2018. 
TOMING, K.; KUTSER, T.; LAAS, A.; SEEP, M.; PAAVEL, B.; NÕGES, T. First experiences in mapping lake water quality parameters with Sentinel-2 MSI imagery. Remote Sensing, v. 8 , n. 8 , p. 640,2016 . https://doi.org/10.3390/rs8080640

VARGAS, R. R.; BARROS, M. S.; SAAD, A. R.; ARRUDA, R. O. M.; AZEVEDO, F. D. Assessment of the water quality and trophic state of the Ribeirão Guaraçau Watershed, Guarulhos (SP): a comparative analysis between rural and urban areas. Revista Ambiente \& Água, v. 13, n. 2, 2018. http://dx.doi.org/10.4136/ambi-agua.2170 